\title{
TOWED ANTI-TANK GUNS RENAISSANCE OF ALMOST FORGOTTEN WEAPONS IN UKRAINIAN CONFLICT
}

\author{
Lukáš DYČKA \\ University of Defence, Brno, The Czech Republic \\ lukas.dycka@unob.cz
}

\begin{abstract}
Russia's operations in Ukraine stand in stark contrast to the old Soviet doctrine of methodical, timetable- and echelon-driven employment of ground forces that sought to outmass the opposing army. Apart from obvious tactical implications and use of some modern equipment, this approach has led to reoccurrence of rather forgotten types of military hardware on the battlefield, most notably the towed anti-tank guns that had profound effect on later stages of the conflict. This article assess the reasons of their reoccurrence, types of these weapons and ammunition used on both sides of the conflict and in the last part tactical use of towed anti-tank guns with possible prospect for the future warfare. Data collection and analysis relied chiefly on media and image analysis both from Russian and Ukrainian sources.
\end{abstract}

\section{Keywords: Russia, Ukraine, Towed anti-tank guns}

\section{Introduction}

1. It could be argued that Russia's operations in Ukraine (2013-present) as well as in Georgia in 2008 provide many interesting insights, but most notably they illustrate a departure from contemporary guerrilla and counterinsurgency operations (dominant of Western armies) and demonstrate the pendulum swinging back toward conventional, high-intensity land warfare.

Firstly, changes to Russian tactics typify the manner in which Russia now employs its ground force. Borrowing from the military theorist Carl von Clausewitz, who stated, "It is still more important to remember that almost the only advantage of the attack rests on its initial surprise," [1] Russia's contemporary operations embody the characteristic of surprise. Russian operations in Ukraine, as well as earlier in Georgia, demonstrate a rapid, decentralized attack seeking to temporally dislocate the enemy, triggering the opposing forces' defeat. Russia's actions in Ukraine have revealed several innovations, most notably the employment of the semi-autonomous battalion tactical group, and a reconnaissance-strike model that tightly couples drones to strike assets, hastening the speed at which overwhelming firepower is available to support tactical commanders. [2] These methods stand in stark contrast to the old Soviet doctrine of methodical, timetable- and echelon-driven employment of ground forces that sought to outmass the opposing army. Current Russian land warfare tactics are something that most armies, including the Czech Armed Forces, are largely unprepared to address.

Conversely, after achieving limited objectives, Russian forces in Ukraine quickly transitioned to the defense using ground forces, modern drones and airdefense capabilities to build a tough, integrated position from which extrication would be difficult, to be sure. [3] Russia's defensive operations do not serve as a simple shield, but rather, as a shield capable of also delivering well-directed, 
concentrated punches on the opposition army.[4] Russia's paradoxical use of offensive operations to set up the defense might indicate an ascendancy of the defense as the preferred method of war in forthcoming conflicts. Apart from obvious tactical implications and use of some modern equipment, this approach has unexpected impact on reoccurrence of rather long forgotten military hardware on the battlefield.

Among the most visible and with highest impact on later phases of Ukrainian conflict were towed artillery pieces, including antitank cannons. Largely omitted in past decades, it can be argued that the towed anti-tank guns played their last important role during the World War II, but the maneuver character of the combat gradually led to the preference of self-propelled antitank guns, also called "tank destroyers". Although many armies continued to use the towed anti-tank cannons, their importance declined as light recoilless guns and later the anti-tank guided missiles replaced them. The only relevant exception was the Soviet Union, which continued to develop, produce and use "classic" (i.e. not recoilless) towed anti-tank guns. Even today, these guns of 85 and $100 \mathrm{~mm}$ caliber could be surprisingly effective artillery weapons, as the conflict in eastern Ukraine has proven.

\section{Historical overview - Development of Soviet Smooth-barreled Cannons in Cold war Era.}

In 1965, the Soviet industry manufactured the first serial examples of new towed antitank gun, but it officially entered the Soviet Army service only in 1961 under the name $\mathrm{T}-12$ or $2 \mathrm{~A} 91$. It had caliber of $100 \mathrm{~mm}$ and it was created by the construction bureau of the Yugrin Machinery Plant as a replacement for previous BS-3 gun of the same caliber. But there was also a distinct difference, because the former gun had got rifled barrel, but the new T-12 had got smoothbore one. This solution was selected due to the possibility of achieving higher pressures (and thus, higher projectile speeds) and longer endurance. The fact that smoothbore barrels are more suitable for HEAT rounds, since the rotation of grenade from the rifled barrel reduces the efficiency of the shaped charge, played also role in its development. The T-12 gun used the carriage and other features of the $85-\mathrm{mm}$ D48 anti-tank gun, the only difference was in fact the barrel. [5] Both types can be easily distinguished by their muzzle brakes, because the brake of D-48 has got a "box" shape, while the brake of T-12 is cylindrical with small holes. The T-12 breech is a vertical block with semi-automatic function, meaning that it needs to be opened manually only before the first shot, but after every following shot, the breech opens automatically itself. The recoil of the gun is lowered not only by the muzzle brake, but also by the hydraulic buffer and recuperator. In 1971, a new variant was introduced, officially called MT-12 (sometimes also $\mathrm{T}-12 \mathrm{~A}$ ) and given the combat name Rapira (meaning "Rapier"). The performance has not changed, but the gun used new carriage with higher endurance, as it was needed for towing by MT-LB armored tractors (while the original $\mathrm{T}-12$ was usually towed by trucks). Their wheels can easily distinguish both variants, since the wheel disc of the T-12 has six screws, while the MT-12 wheel disc (identical to ZIS-150 truck disc) has eight screws.

\subsection{Ammunition types and special variants}

The main device for aiming of the MT-12 in good visibility is the OP4MU-40U optical sight, while in the night, the crews use the APN-6-40 sight, also known as "Brusinka" (Russian for "Cranberry"). But the gun can be equipped also with other types of night sights, such as the 1PN35, 1PN53 or APN-7. [6] The MT-12 gun is also able of indirect fire, thus, it is equipped with S71-40 mechanical artillery sight, PG$1 \mathrm{M}$ panoramic telescope and $\mathrm{K}-1$ collimator 
sight. Coincidently this feature plays significant role in Ukrainian conflict. The default ammunition stock is twenty rounds, including ten solid armor-piercing rounds (BPS), six HEAT shaped-charge rounds (KS) and four high-explosive grenades (OFS) against "soft" targets (their specifications are found in the table). Besides the main MT-12 variants, there were also smaller amounts of two special models, equipped with additional sensors. The MT-12K (2A29K) gun has got a laser device for guidance of the anti-tank guided missiles (in Russian, called "PTUR") of the 9K116 Kastet ("Knuckle") system. Its 9M117 missile is launched with a special round and is guided semi-automatically with laser-beam-driving method. Its range is about $4000 \mathrm{~m}$ and it is able to penetrate reactive protection and layered armor equal to $550 \mathrm{~mm}$ RHA.[7] For comparison, the "classic" armor-piercing grenades of MT12 can penetrate armor of about $215 \mathrm{~mm}$ RHA (the armor of M60 and Leopard 1 tanks) at $1000 \mathrm{~m}$. The second special version of the gun is known as MT-12R (2A29R) and is equipped with a small radar, called 1A31 Ruta ("Rue") and developed for the detection and aiming of targets at distances up to $3500 \mathrm{~m}$. Both variants were introduced in the service in 1981 and were not exported outside of the USSR, while the basic MT-12 was massively sold to the Warsaw Pact and Third World countries. The Russian Army actively uses about 520 guns [8] (and about two thousands are stored) and several hundreds can be found in arsenals of at least fourteen other countries of the world.

\section{Use of Towed Anti-tank Guns in the Donbass Conflict}

Before the outbreak of the conflict in eastern Ukraine, the Ukrainian army possessed slightly over five hundreds of the T-12, MT-12 and MT-12R cannons (but probably no "rocket" MT-12K guns). Usage of towed anti-tank guns by the Ukrainian army against the pro-Russian separatists in Donbass was at first documented in their original role, and it was soon proven that, while morally obsolete, these $100-\mathrm{mm}$ cannons could still be efficient weapons. While they could not penetrate the frontal armour of modern main battle tanks, it is worth mentioning that "modern" tanks are very rare in the eastern Ukraine conflict. The most common type is the T-64 tank, whose front armour can be penetrated by $100-\mathrm{mm}$ rounds at smaller distances. And this type of ammunition is in any case wholly adequate for penetrating side armor of T-64 tank and it can in any case easily destroy all lighter armored vehicles used on the Donbass battlefield. The main drawback of the MT-12 gut is its limited mobility, for which it is only of limited use in maneuvering combat - consequently in this type of operations 100-mm cannons suffered greatest losses mostly due to mechanical breakdowns and counter-battery fire by the Russian military. [9]

The largest maneuver tank battles took place in the summer 2014 and the initial results of the Ukrainian army against the separatists were satisfactory, but after the regular Russian army units joined the conflict, the situation changed. In the September 2014, the Ukrainian army suffered the fatal defeat near Ilovaysk and the frontline was stabilized. Up until this point, towed guns were rarely seen, because maneuverable warfare preventeted their wider employment. But after defeat near Ilovaysk the frontline became more static and this class of weapons appeared on both sides of the front in larger numbers. In the combat from the September 2014 to February of 2015, towed artillery played significant role. The MT-12 guns were often seen during the battle of Debaltseve in the January 2015, this time on both sides, because the separatists captured several pieces (or were supplied with them by Russia).[10] The city formed a salient into Russian- and separatist-controlled territory, which offered Russia an enticing opportunity to shore up its front lines. On 
January 14, 2015, Russian and separatist forces attacked, aiming to collapse the shoulders of the salient and cut off the Ukrainians in the city - a pincer movement reminiscent of the Battle of the Bulge. Once isolated, Russian forces launched massive salvos of rocket and artillery fire at Ukrainian forces. The Ukrainian army had to abandon its positions and in the February 2015, the new ceasefire agreement (also known as "Minsk II") was negotiated. While it is still in power, the situation in eastern Ukraine remains risky and dangerous.

\subsection{Re-emergence of the 85-mm guns}

At the same time with the "Minsk II" negotiations, the media also published several pieces of news about efforts of Ukrainian army to strengthen its artillery capabilities [11]. The Ukrainians decided to re-activate certain types of weapons, which were stored in the reserve storage and belong, in fact, to the "museum" category, since they were developed in the beginning of the Cold War.[12] However, employment of older artillery pieces on the battlefield was dictated (more than anything else) by terrible losses Ukrainian army suffered during the war. Comparing the 2013 and 2016 editions of the Military Balance shows that between 2013 and 2016 Ukraine has lost $29 \%$ of its tanks, $56 \%$ of its armored personnel vehicles, $66 \%$ of its infantry fighting vehicles and $44 \%$ of its artillery. This included $56 \%$ of its selfpropelled artillery and a whopping $80 \%$ of its light artillery. [12] Thus activated weapons included the 152-mm D-20 (52-P546) howitzers, which were introduced in 1955 , and two types of towed cannons of 85 $\mathrm{mm}$ caliber that were designed by the famous F. F. Petrov from the Ural Machinery Plant. The first one is the D-44 (52-P-367) divisional gun, introduced into service in 1946. Its design was also the basis for the second type, the already mentioned D-48 (52-P-372) anti-tank cannon, which entered service seven years later (and its carriage was later used for the
T-12 cannon). The D-44 and D-48 guns possess rifled barrels with the length of 55 or 74 calibers, respectively. Their breech is again the vertical block and the range of ammunition includes solid armor-piercing, HEAT and high-explosive grenades. The 85$\mathrm{mm}$ armor-piercing round could penetrate armor of $185 \mathrm{~mm}$ RHA at the distance of $1000 \mathrm{~m}$. It is still surprisingly efficient against older vehicles, and moreover, these guns are also capable of indirect fire; the full range of the D-48 is about $19 \mathrm{~km}$. Reports from the battlefield indicate, that with ceasfire measures in place, indirect fire became "daily bread" for this class of weapons, since larger caliber guns were withdrawn from the frontline. [14]

While these guns are morally absolutely obsolete, their firepower simply cannot be ignored. And they also have one very special feature, which could be even the decisive factor for the Ukrainian army. The "Minsk II" agreement determined the distance of $50 \mathrm{~km}$ from the frontline to be cleared of "heavy artillery", i.e. weapons of $100-\mathrm{mm}$ caliber or higher. But the $85-\mathrm{mm}$ guns logically don't fall under this regulations, thus, they could be placed in the nearest distance of the line. This could be taken as a warning that the situation is very tense, and as the recent events in the Ukraine demonstrated that a "hot" conflict can erupt in every moment. And in that case, the towed anti-tank guns can be seen in combat again.

\section{Conclusions}

The battlefields in Eastern Ukraine represent part of a new era of warfare, or so we are regularly told. Analysts, pundits, and military leaders point to cyber warfare, hybrid warfare, and the gray zone. But look away from these shiny new concepts for a moment, and it becomes clear the RussianUkrainian war's conventional character is far from new. In fact, it looks a lot like the last century's World Wars. While the new aspects of this war have generated discussion within the defense industry as to 
the evolving character of war, an acknowledgement of the conflict's conventional character is largely missing from the discourse. This case could be ideally illustrated on towed anti-tank artillery used in the conflict. Of course, self-propelled artillery is much more effective in terms of active defence operations. But towed anti-artillery, with all its slowness, requires little attention in terms of the material and technical support. Moreover its ability to be used in indirect fire makes them weapon ideally suited for prolonged positional warfare that dominates last two years of Ukrainian conflict.

\section{Acknowledgements}

The work presented in this paper has been supported by the Ministry of Defence of the Czech Republic (Research Project "STRATAL" No. 907930101023).

Special thanks also goes to Mr. Lukáš Visingr for his constant and unwavering support during writing this article.

\section{References}

[1] Fox, Amos C., Russian Hybrid Warfare and the Re-emergence of Conventional Armored Warfare: Implications for the U.S. Army's Armored Force, 2015. Available on: http://www.benning.army.mil/armor/earmor/content/issues/2016/JUL_SEp/3FoxRussia16.pdf

[2] Fox, Amos C., The Russian-Ukrainian War: Understanding the Dust Clouds on the Battlefield, Modern War Institute, West Point, USA, 2017. Available on: http://mwi.usma.edu/russian-ukrainian-war-understanding-dust-clouds-battlefield/

[3] Krushelnycky, Askold., Preparing for Trench Warfare in Ukraine, The Intercept, 2015, Available on: https://theintercept.com/2015/04/04/ukraine-trench-warfare/

[4] Fox, Amos C., Russian Hybrid Warfare and the Re-emergence of Conventional Armored Warfare: Implications for the U.S. Army's Armored Force, 2015. Available on: http://www.benning.army.mil/armor/earmor/content/issues/2016/JUL_SEp/3FoxRussia16.pdf

[5] Širokorad, A. В., Энциклопедия отечественной артиллерии, Charvest, Minsk, Belarus, 2000. ISBN 985-433-703-0, pp. 621-632.

[6] http://www.russianarms.ru/forum/index.php?topic $=860.0$

[7] http://www.russianarms.ru/forum/index.php?topic $=860.0$

[8] Fox, Amos C., Russian Hybrid Warfare and the Re-emergence of Conventional Armored Warfare: Implications for the U.S. Army's Armored Force, 2015. Available on: http://www.benning.army.mil/armor/earmor/content/issues/2016/JUL_SEp/3FoxRussia16.pdf

[9] Fox, Amos C., The Russian-Ukrainian War: Understanding the Dust Clouds on the Battlefield, Modern War Institute, West Point, USA, 2017. Available on: http://mwi.usma.edu/russian-ukrainian-war-understanding-dust-clouds-battlefield/

[10] Fox, Amos C., The Russian-Ukrainian War: Understanding the Dust Clouds on the Battlefield, Modern War Institute, West Point, USA, 2017. Available on: http://mwi.usma.edu/russian-ukrainian-war-understanding-dust-clouds-battlefield/

[11] Украина восстанавливает старые советские орудия. 2015. Available on: http://bmpd.livejournal.com/1276990.html

[12] Kmitits, A., Artillery in Ukraine: observations from the line of battle, Belarus Security Blog, Minsk, Belarus, 2016. Available on: https://www.bsblog.info/artillery-in-ukraineobservations-from-the-line-of-battle/

[13] Mercouris, A., Details of Ukrainian Equipment Losses Confirm Scale of Ukraine's Defeat, TheDuran.com, 2016. Available on: http://theduran.com/confirmationukrainian-equipment-losses-confirms-scale-ukraines-defeat/ 
[14] Kmitits, A., Artillery in Ukraine: observations from the line of battle, Belarus Security Blog, Minsk, Belarus, 2016. Available on: https://www.bsblog.info/artillery-in-ukraineobservations-from-the-line-of-battle/ 